\title{
Influence of a trout farm on antioxidant defense in larvae of Ephemera danica (Insecta: Ephemeroptera)
}

\author{
Milenka L.J. Božanić ${ }^{1}$, Dajana D. Todorović ${ }^{2}$, Miroslav Ž. Živić ${ }^{1}$, Vesna D. Perić-Mataruga ${ }^{2}$, \\ Zoran Z. Marković ${ }^{3}$ and Ivana M. Živić ${ }^{1{ }^{*}}$ \\ ${ }^{1}$ Faculty of Biology, University of Belgrade, 11000 Belgrade, Serbia \\ ${ }^{2}$ Institute for Biological Research "Siniša Stanković", University of Belgrade,11060 Belgrade, Serbia \\ ${ }^{3}$ Faculty of Agriculture, University of Belgrade, 11080 Belgrade, Serbia
}

\begin{abstract}
The aim of this study was to establish the influence of a trout farm on the activity of enzymes superoxide dismutase (SOD) and glutathione peroxidase (GPx), and total glutathione concentration (GSH), in larvae of Ephemera danica, and on environmental parameters in the receiving watercourse. The investigations were carried out seasonally (April, July, and October of 2016 and January of 2017) at four localities (SK1 - control, and SK2, SK3, and SK4 -30 m, $330 \mathrm{~m}$ and $630 \mathrm{~m}$ below the fish farm, respectively) along the Skrapež River. Discharged water had the greatest effect on the concentrations of dissolved oxygen (DO), ammonium ions, nitrates $\left(\mathrm{NO}_{3}{ }^{-}\right)$, and total phosphorus. In the case of SOD and $\mathrm{GSH}$, seasonal changes were greater than longitudinal, with maximal values attained in spring and summer and minimal in autumn and winter. SOD showed the strongest correlation with DO, and GSH with total nitrogen. Activity of GPx demonstrated greater longitudinal variability with maximum at SK2 in all seasons and the strongest correlation with $\mathrm{NO}_{3}{ }^{-}$. The obtained results indicate that GPx activity was the most sensitive to the trout farm effects, while SOD and GSH were more influenced by natural seasonal changes of environmental parameters.
\end{abstract}

Keywords: oxidative stress / Ephemera danica / trout farms

Résumé - Influence d'un élevage de truites sur la défense antioxydante des larves d'Ephemera danica (Insecta : Ephemeroptera): L'objectif de la présente étude était d'établir l'influence d'un élevage de truites sur l'activité des enzymes superoxyde dismutase (SOD) et glutathion peroxydase (GPx), et la concentration totale de glutathion (GSH), chez les larves d'Ephemera danica, et sur les paramètres environnementaux dans le cours d'eau récepteur. Les investigations ont été menées de façon saisonnière (avril, juillet et octobre 2016 et janvier 2017) dans quatre localités (SK1 - contrôle et SK2, SK3 et SK4 $30 \mathrm{~m}, 330 \mathrm{~m}$ et $630 \mathrm{~m}$ en aval de la pisciculture respectivement) le long de la rivière Skrapež. L'eau rejetée a eu le plus grand effet sur les concentrations d'oxygène dissous (OD), d'ions ammonium, de nitrates $\left(\mathrm{NO}_{3}{ }^{-}\right.$) et de phosphore total. Dans le cas de la SOD et de la GSH, les variations saisonnières ont été supérieures aux variations longitudinales, les valeurs maximales étant atteintes au printemps et en été et minimales en automne et en hiver. La SOD a montré la plus forte corrélation avec l'OD et le GSH avec l'azote total. L'activité de la GPx a démontré une plus grande variabilité longitudinale avec un maximum à SK2 en toutes saisons et la plus forte corrélation avec $\mathrm{NO}_{3}{ }^{-}$. Les résultats obtenus indiquent que l'activité de la GPx était la plus sensible aux effets de l'élevage de truites, alors que la SOD et la GSH étaient plus influencées par les changements saisonniers naturels des paramètres environnementaux.

Mots-clés : stress oxydatif / Ephemera danica / élevage de truites

\section{Introduction}

Various economic activities such as manufacturing, mining, agriculture, canal building, and construction of water

\footnotetext{
*Corresponding author: ivanas@bio.bg.ac.rs
}

supply reservoirs exert great influence on highland streams, which are vital components of the river network (Gavrilović and Dukić, 2002; Estevez et al., 2017). Significant influence on these watercourses is also exerted by the increasingly frequent construction of trout farms on their banks, since rainbow trout as the most cultivated cold-water species requires precisely 
this type of habitat (Woynarovich et al., 2011). Rearing of fish on trout farms involves a multiple increase of ichthyomass per unit of area compared to natural population. This is achieved by supplementary feeding, with consequent increased pollution of the recipient stream, which soon results in disturbed functioning of the ecosystem and has a negative effect on communities of aquatic invertebrates (Loch et al., 1996; Živić et al., 2009a; Soofiani et al., 2012; Imanpour et al., 2013).

Among the most common causes of contamination of river courses by trout farms are unconsumed feed and fish feces (Kronvang et al., 1993; Iversen, 1995; Boyd, 2003; Namin et al., 2013). Because the waters from fish farms after use are most often discharged into the recipient stream without any prior treatment in the form of settling and purification (Tello et al., 2010), there is serious deterioration of water quality with worsening of the recipient stream's bottom structure (Weston et al., 1996). For this reason, it is necessary to conduct constant monitoring of the influence of discharge waters from the fish farm on the recipient stream, for which, in addition to traditional methods of chemical analysis, communities of macroinvertebrates are employed with increasing frequency (Bonada et al., 2006; Carter et al., 2006; Živić et al., 2009a,b), organisms of the order Ephemeroptera above all others being used here as bioindicators of pollution of mountain streams (Brittain and Sartori, 2003; Lock and Goethals, 2011; Bauernfeind and Soldan, 2012). Owing to their characteristic way of life, limited mobility, sensitivity to organic pollution, wide distribution, and relatively large body size, larvae of Ephemera danica are suitable organisms on which to investigate the influence of trout farms on wildlife in recipient stream. They are indicators of good water quality, on the boundary between the oligo- and betamesosaprobic classes (Winkelmann and Koop, 2007; Bennett, 2007). The larval stage usually lasts 1 or 2 years, and cases of its lasting up to 3 years are not rare, which makes it possible to follow the long-term effects of all environmental influences, including that of fish farms.

Determination of the activity of antioxidant enzymes (superoxide dismutase, catalase, glutathione peroxidase, reductase, and transferase) and the content of smaller molecules having a role in antioxidant protection (vitamins $\mathrm{C}$, $\mathrm{A}$, and E; glutathione; coenzyme Q; cysteine; etc.) in aquatic organisms is very important because they represent biomarkers of oxidative stress and are used in biomonitoring of land-based waters (Valavanidis et al., 2006; Vranković et al., 2012; Vranković and Slavić, 2015; Vranković, 2016; Mirčić et al., 2016). Under the influence of altered abiotic factors of the aquatic environment, formation of reactive oxygen species (ROS) and their increased production occur in organisms, which lead to further oxidative stress in them (Halliwell and Gutteridge, 1999; Lushchak, 2011). As a consequence of the reactivity of ROS and their potential ability to damage cells and tissues, many organisms balance the presence of these radicals with a wide range of cellular antioxidant systems of protection (Buonocore et al., 2010). Maintenance of this balance is of fundamental significance for physiological health of the organism and equilibrium between production and elimination of ROS is crucial for cellular homeostasis (Lemaire and Livingstone, 1993).

The effects of trout farms on the living world of streams have been rarely investigated on the molecular level. This most often involves monitoring the activity of antioxidant enzymes, which can indicate increase of oxidative stress in an organism due to anthropogenic changes in its surroundings. Where larvae of aquatic insects are concerned, such investigations are relatively rare (Choi et al., 1999; Berra et al., 2004; Barata et al., 2005; Mirčić et al., 2016; Božanić et al., 2017; Radojević et al., 2017). However, the attention of investigators is being increasingly drawn to such investigations because they open the possibility of predicting the effects of pollution (under the influence of trout farms in the present case) on populations through the response of individual specimens (E. danica) to stress. It is known that a response to the presence of pollutants is manifested earlier on the level of organisms than on the level of the whole community (Gremyatchikh et al., 2009). The building of trout farms represents a profitable branch of economy (Marković et al., 2009), and because Serbia is in a geographical position suitable for this activity, their number is constantly increasing (there are currently between 120 and 130 trout farms in the country). For this reason, it is necessary to pay attention to the pollution that arises as a consequence of the discharge of wastewater from fish farms, and our investigation was realized with the aim of determining the influence of a trout farm on components of antioxidative defense in larvae of E. danica as a model organism sensitive to pollution.

\section{Material and methods}

\subsection{Description of investigated localities}

The Skrapež is a river in Western Serbia and the largest tributary of the Djetinja River (Fig. 1). It has a length of $47.7 \mathrm{~km}$ and drainage area of $647.65 \mathrm{~km}^{2}$ (Gavrilović and Dukić, 2002). The "Kraj vodenica" trout farm has a total production area of $588 \mathrm{~m}^{2}$ and is located in the wider region of the village of Radanovci on the left-hand bank of the Skrapež River about $2 \mathrm{~km}$ downstream from the "Taorska vrela" spring. The fish farm consists of four independent basins in which the fish are fed extruded feed (Skreting Optiline he 3p gal) with low phosphate content of $0.9 \%$ and $42-44 \%$ protein. In the year of the investigation, the production capacity of the fish farm was 29 tons. Water from the trout farm is emptied via a common canal into the recipient stream after passing through a settling tank. Fish are present on the trout farm throughout the year, with maximal biomass in January and minimal in April.

Macrozoobenthos sampling was conducted at four localities. The first (control) locality was at a distance of $180 \mathrm{~m}$ upstream from the fish farm at an elevation of $573 \mathrm{~m}$ a.s.1. (above sea level), latitude of $44^{\circ} 04^{\prime} 00.8^{\prime \prime} \mathrm{N}$, and longitude of $19^{\circ} 50^{\prime} 13.3^{\prime \prime}$ E. Locality SK2 was at a distance of $30 \mathrm{~m}$ downstream from the fish farm at an elevation of $566 \mathrm{~m}$ a.s.1., latitude of $44^{\circ} 03^{\prime} 55.9^{\prime \prime} \mathrm{N}$, and longitude of $19^{\circ} 50^{\prime} 21.2^{\prime \prime} \mathrm{E}$. At an elevation of $552 \mathrm{~m}$ a.s.1., locality SK3 was at a distance of $300 \mathrm{~m}$ downstream from the second locality at a latitude of $44^{\circ} 03^{\prime} 47.8^{\prime \prime} \mathrm{N}$, and longitude of $19^{\circ} 50^{\prime} 28.6^{\prime \prime}$ E. Finally, locality SK4 was at a distance of $300 \mathrm{~m}$ downstream from the third locality at an elevation of $550 \mathrm{~m}$ a.s.l., latitude of $44^{\circ} 03^{\prime} 40.9^{\prime \prime} \mathrm{N}$, and longitude of $19^{\circ} 50^{\prime} 28.1^{\prime \prime} \mathrm{E}$ (Fig. 1).

\subsection{Sample taking and identification}

Larvae of E. danica were collected in April, July, and October of 2015 and in January of 2016 by the qualitative 


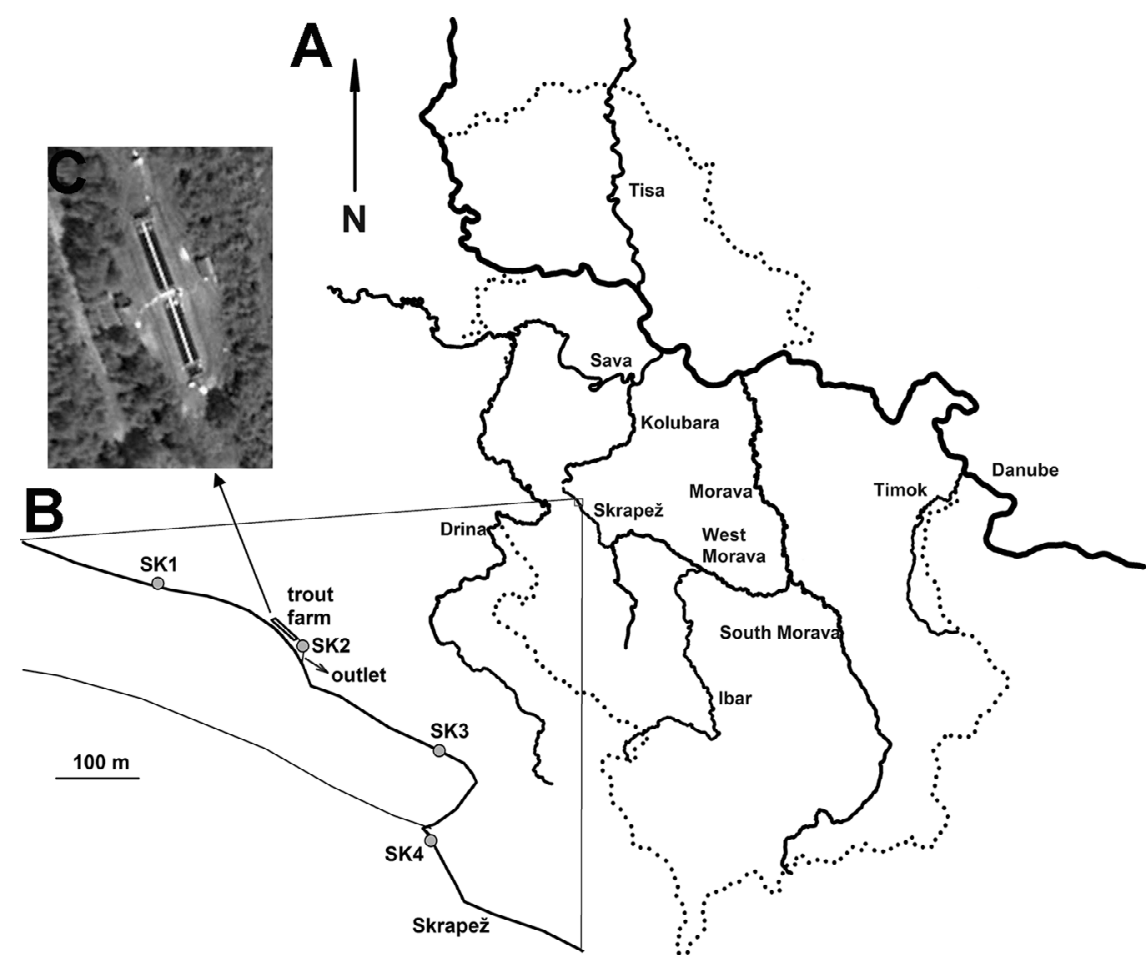

Fig. 1. (A) Geographical location of the Skrapež River in Serbia. Grey rectangle represents position of the study area on the Skrapež River. (B) Locations of the sampling sites (grey circles) on the Skrapež River. The trout farm position is marked with a rectangle. (C) Google earth image of the trout farm at the Skrapež River.

method using a benthos sieve and tweezers. At each locality, 20-25 individuals were collected and directly in the field transferred to a cryocontainer with liquid nitrogen, in which they were transported to the laboratory, where they were weighed on a balance with a precision of $0.0001 \mathrm{~g}$ (an AE163 instrument from Mettler-Toledo International). At each locality, several larvae were collected and fixed in $96 \%$ ethanol for identification. Identification was performed with the aid of a Zeiss Discovery V8 stereomicroscope (Carl ZEISS $\mathrm{GmbH}$, Austria) on the basis of keys for identification (Nilsson, 1996; Bauernfeind and Soldan, 2012).

\subsection{Analysis of physical and chemical parameters of the water}

The following physical parameters of the environment were measured during the investigation: water temperature, current velocity, and depth and width of the riverbed. Water temperature (WT) was measured with a MULTI 340i/SET device (WTW, Germany), which was also used to measure chemical parameters, viz., dissolved oxygen concentration (DO) and saturation (DO\%), $\mathrm{pH}$, and electroconductivity (ec). Depth and width of the riverbed were measured with the aid of a tape measure. Elevation of the localities above sea level and their geographic latitude and longitude were confirmed with the aid of a GPS device (Geko 201, Garmin). Water flow rates $(Q)$ were calculated from the cross-sectional area and longitudinal velocity data for each sampling site. The crosssectional area was first determined by depth $(d)$ and width $(w)$ measurements and then divided into vertical sections where river velocity $(v)$ was measured using a GEOPACKS Stream Flowmeter (Geopacks, UK).

At each locality, a single sample of water for chemical analysis was taken with a 500-ml plastic bottle at a depth of $30 \mathrm{~cm}$ below the water's surface. Chemical parameters were analyzed at the Agency for Environmental Protection in Belgrade by standard methods (SRPS ISO/IEC 17025:2006, ISO/IEC 17025:2005, http://www.sepa.gov.rs). The following chemical parameters were analyzed: water hardness (WH), and concentrations of ammonium ions $\left(\mathrm{NH}_{4}{ }^{+}\right)$, nitrites $\left(\mathrm{NO}_{2}{ }^{-}\right)$, nitrates $\left(\mathrm{NO}_{3}{ }^{-}\right)$, total nitrogen $\left(\mathrm{N}_{t}\right)$, orthophosphates $\left(\mathrm{PO}_{4}{ }^{3-}\right)$, and total phosphorus $\left(\mathrm{P}_{t}\right)$. Unionized ammonia $\left(\mathrm{NH}_{3}\right)$ concentration was calculated according to Newman (1995). Measurements of all environmental parameters were performed in duplicate to ensure representativeness and average values obtained from the two measurements were used for further statistical analysis.

\subsection{Preparation of homogenates and determination of SOD and GPx activity and GSH content}

Up to the time of homogenate preparation, larvae were kept in the laboratory at $-80^{\circ} \mathrm{C}$. Homogenates of whole larvae (170 mg of fresh larval mass on the average) were used to determine the components of antioxidative defense. Larvae were homogenized (three cycles of $10 \mathrm{~s}$ with 15 -s pauses at $2000 \mathrm{rpm}$ ) on ice in $0.25 \mathrm{M}$ sucrose buffer (EDTA; Serva, Heidelberg, Germany). The concentration of protein was determined by the Bradford method (Bradford, 1976) using bovine serum albumin (Sigma-Aldrich Chemie, Steinheim, 
Germany) as the standard. Activity of superoxide dismutase was determined according to the procedure of Misra and Fridovich (1972). The enzymatic method of Tamura et al. (1982) was used to determine activity of glutathione peroxidase. The content of glutathione was determined in homogenates in which proteins were precipitated with sulphosalicylic acid (Griffith, 1980).

Ten independent samples (homogenates) from each sampling occasion were used to determine the activity of antioxidant enzymes (SOD and GPx) and content of GSH. For each of them, the mentioned biomarkers were simultaneously measured three times using a Shimadzu UV-160 spectrophotometer (Shimadzu Corporation, Kyoto, Japan) to ensure representativeness and average values obtained from the three measurements were used for further statistical analysis.

\subsection{Statistical analyses}

All data were expressed as mean \pm standard error. In order to take into account both locality and seasonal variability, the activity of antioxidant enzymes (SOD and GPx) and GSH content were compared statistically using two-way analysis of variance (two-way ANOVA). The values of abiotic parameters (hydrological and chemical parameters of the water) at investigated localities were compared statistically to either control locality (SK1), to assess the trout farm effect, or to the downstream locality nearest to the farm outlet (SK2), to assess recovery, using one-way ANOVA. In both cases, pairwise comparisons were made with the Holm-Sidak test. The strength of association among pairs of variables was measured by the Pearson product moment correlation. The results were considered to be statistically significant at $P<0.05$. The two-way ANOVA, one-way ANOVA, and determination of the Pearson product moment correlation were performed with the aid of the Sigma Plot 12 software (Systat Software Inc., USA).

Environmental data were analyzed together with data on the activity of antioxidant enzymes and content of GSH using co-inertia analysis (CIA) (Dolédec and Chessel, 1994). Co-inertia axes were calculated by maximizing the covariance of factorial scores generated in separate ordinations of the two input tables (in this study, the correlation matrix of principal component analysis (PCA) for the environmental variables and the antioxidant biomarkers data). The Monte-Carlo permutation test was used to check significance of the co-structure between the two data sets as revealed by CIA. Co-inertia analysis was computed using the ADE-4 software (Thioulouse et al., 1997).

\section{Results}

\subsection{Influence of the trout farm on antioxidative defense}

Two-factor analysis of variance indicated that the activities of SOD and GPx and concentration of GSH vary with statistical significance $(P<0.001)$ both from locality to locality and throughout the year, and that statistically significant interaction exists between these two factors, which means that seasonal changes exert significant influence on longitudinal changes and vice versa. However, there are significant differences in the form of changes in activity of SOD and GPx (Fig. 2).

Activity of SOD is characterized by greater seasonal than longitudinal variability. Thus, statistically significant differences of SOD activity exist in all seasons, but not between localities (Fig. 2A). At the control locality (SK1), a monotonic decline of SOD activity occurs from spring to winter. A similar trend is maintained downstream from the inflow of wastewater from the fish farm, with the qualification that due to SOD activity decrease in spring, the difference in values of this index in spring and summer is lost. Analysis of longitudinal changes clearly indicates that there are no differences of SOD activity at the different localities in summer and winter. In spring, the activity of SOD is higher at the control locality (SK1), which lies above the fish farm, than at the locality immediately below the farm (SK2), where a decrease of activity occurs. The most intensive changes are characteristic of the autumn season, when SOD activity attains a statistically significant maximum at locality SK2 after inflow of wastewater from the fish farm.

Glutathione peroxidase activity is characterized by greater longitudinal than seasonal variability. Thus, there is no statistically significant seasonal variation in the activity of GPx at the control locality (Fig. 2B). The situation is similar at localities SK3 and SK4, with the exception of activity in winter, which at SK3 is lower than activity in autumn, and at SK4 is higher than activity in the other seasons. In contrast to this, at SK2 well-expressed seasonal changes of GPx activity occur that are characterized by a pronounced decrease in summer and subsequent gradual but incomplete recovery until winter (Fig. 2B). As for longitudinal changes, a large and statistically significant increase of GPx activity occurs in all seasons at locality SK2 in relation to the control locality, this increase being accompanied by recovery of values at SK3 in all seasons except autumn, when the values at both downstream localities remain statistically significantly higher than at the control locality.

The concentration of total glutathione very closely follows changes of SOD activity and the two indices are characterized by a high degree of correlation $(R=0.862, P<0.001$; Fig. 2D), which is not the case with GPx activity $(R=-0.192, P=0.48)$. Like SOD activity, the concentration of glutathione is characterized by greater seasonal than longitudinal variability. The concentration of GSH likewise declines throughout the year, but unlike SOD activity it attains a minimum in autumn instead of winter, except at SK2 (Fig. 2C). With respect to differences from locality to locality, glutathione concentration, like SOD activity, attains a maximum in spring at the control locality, but in autumn at SK2. In the summer and winter periods, GSH is characterized by longitudinal variability greater than that of SOD, since both seasons are characterized by a statistically significant minimum at SK2 (Fig. 2C).

\subsection{Comparative analysis of biomarkers and abiotic parameters}

Co-inertia analysis (CIA) was used to investigate the influence of changes in water chemistry and hydrology caused 


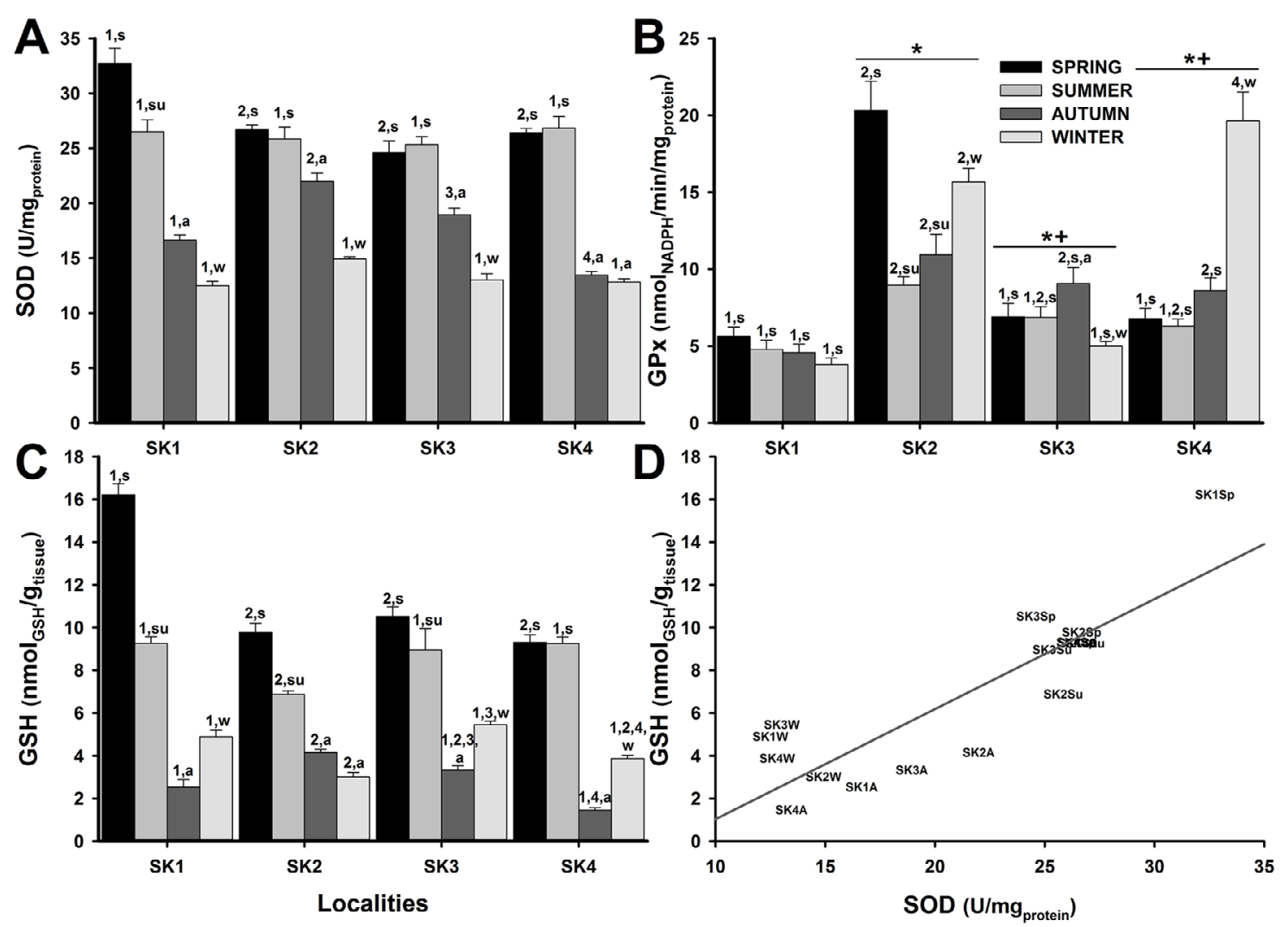

Fig. 2. Changes in average activities of superoxide dismutase (SOD) (A) and glutathione peroxidase (GPx) (B), and average concentration of total glutathione $(\mathrm{GSH})(\mathrm{C})$ in larvae of E. danica $(n=10)$ at four investigated localities (SK1, SK2, SK3, and SK4) along the Skrapež River during different sampling seasons (spring, summer, autumn, and winter). Samples at different localities taken in the same season that are significantly different are marked with different numbers $(1,2,3,4)$. Samples from different seasons taken at the same locality that are significantly different are marked with different letters $(\mathrm{s}, \mathrm{su}, \mathrm{a}, \mathrm{w})$. Statistically significant difference $(P<0.05)$ of values at downstream localities compared to the values at the control locality (SK1) is marked with an asterisk $\left(^{*}\right)$, and compared to the values at SK2 locality with a plus (+). (D) Effect of changes in SOD activity during the investigation period on the concentration of GSH at the investigated localities on the Skrapež River. The solid line represents the linear fit of the data $(R=0.862, P<0.001)$.

by receipt of the trout farm's wastewater on the activity of two antioxidant enzymes and concentration of total glutathione in E. danica (Fig. 3). The results of CIA showed that there was a statistically highly significant $(P<0.001)$ co-structure between the correlation matrix PCA of antioxidant biomarkers and the correlation matrix PCA of water hydrology and chemistry data. In graphi graphic representation of the observed co-structure, two factorial axes were retained that explain almost the entire (95\%) co-structure $(F 1=65 \%$, $F 2=30 \%)$. Strength of the co-structure was confirmed by the relatively high values of correlation coefficients along the $F 1$ axis (0.89) and $F 2$ axis (0.84).

Analysis of the position of samples along the $F 1$ axis in relation to both abiotic factors (origins of black arrows) and biomarkers (arrowheads of black arrows) shows that they are aligned in regular chronological order starting from spring and summer samples at the positive end of the $F 1$ axis (Fig. 3). Therefore, the $F 1$ axis is clearly the axis of seasonal changes. It follows that parameters strongly associated with the $F 1$ axis characterize seasonal changes to a greater extent than longitudinal ones. And indeed, SOD and GSH, which were shown to be characterized by significantly greater seasonal variability, are closely grouped at the negative end of the $F 1$ axis, since their spring and summer values (Fig. 2) are significantly greater than those recorded in autumn and winter. Of abiotic factors, the strongest connection with the $F 1$ axis is exhibited by WT and $\mathrm{N}_{t}$ with its negative end, and by DO and ec with its positive end, a somewhat weaker connection with the negative end of the $F 1$ axis being realized by $\mathrm{WH}, \mathrm{NH}_{3}$, and $\mathrm{pH}$. In the case of these parameters (with the exception of DO), seasonal variability is significantly greater than longitudinal variability, and they are oriented toward the negative end of the $F 1$ axis and attain maximum values in spring or summer and minimum values in autumn or winter (Fig. 4A, D, E, H, J), whereas the situation is reversed with abiotic factors oriented toward the positive end (Fig. 4C, F). The value of DO is characterized by equal seasonal and longitudinal variability, since a statistically significant minimum is achieved at SK2 and it reaches maximal values in winter (Fig. 4C). The results of CIA indicate that these abiotic parameters should have the greatest influence on changes of SOD and GSH. Correlation analysis confirms this, since SOD 


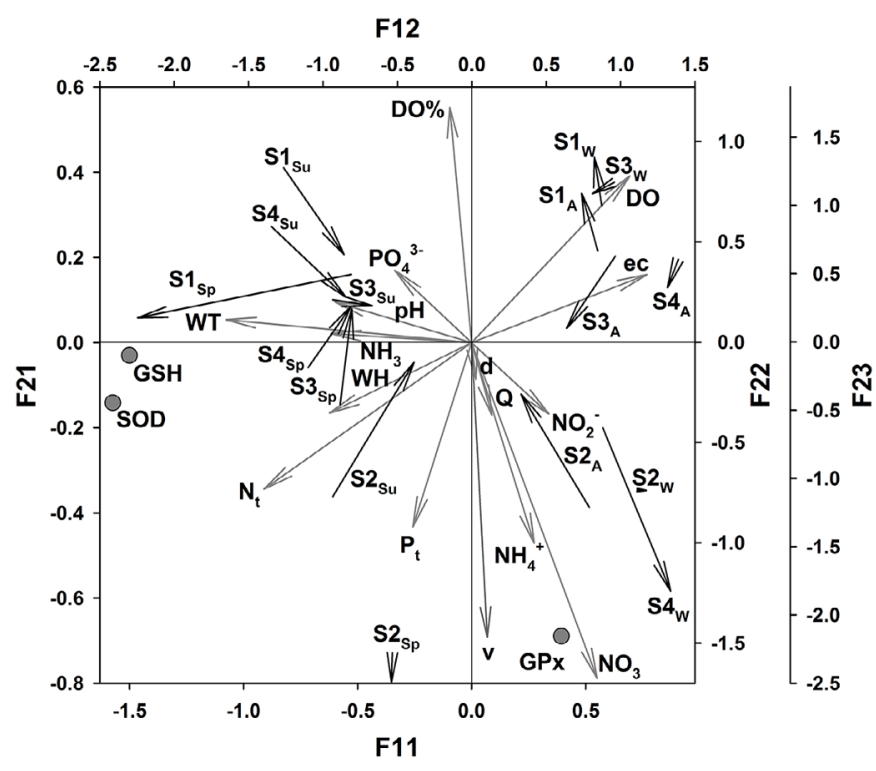

Fig. 3. Triplot presentation of the co-inertia analysis (CIA) of 16 environmental variables and three antioxidant biomarkers performed on 16 samples [four sites, SK1-SK4, sampled four times, viz., in spring (Sp), summer (Su), autumn (A), and winter (W)]. The ordination diagram of 15 normalized environmental variables (see Material and Methods section for codes) in the CIA is represented by grey arrows starting from the origin and projected onto the F11 $\times$ F2 1 factorial map. Positions of antioxidant biomarkers (grey circles) are plotted onto the CIA F11 $\times$ F22 plane (see Material and Methods section for codes). Standardized co-inertia scores of environmental and antioxidant biomarker data for each sample (black arrows) are projected onto the F12 $\times$ F 23 factorial map. The arrow origin locates the sample as ordinated by the environmental variables, and the arrowhead locates it as ordinated by values of the antioxidant biomarkers.

is characterized by statistically significant correlation with WT $(R=0.834, P<0.001)$, DO $(R=-0.678, P=0.004$; Fig. 5B), WH $(R=0.567, P=0.022)$, and $\mathrm{N}_{t}(R=0.592$, $P=0.016)$, while GSH is statistically significantly correlated with WT $(R=0.647, \quad P=0.006), \quad \mathrm{pH} \quad(R=0.499$, $P=0.049), \quad$ ec $\quad(R=0.655, \quad P=0.006), \quad$ and $\quad \mathrm{N}_{t}$ $(R=0.771, P<0.001 ;$ Fig. 5C).

If the $F 1$ axis primarily accounts for seasonal changes in abiotic and biotic parameters, the $F 2$ axis is clearly the axis of longitudinal changes. Along the $F 2$ axis samples taken immediately downstream from the fish farm (at the SK2 locality) from each sampling season are clearly separated from those taken in the same season at the reference locality and localities farther downstream (SK3 and SK4). Therefore, F2 can be named as the axis of trout farm influence. Activity of GPx - shown to be characterized by significantly greater longitudinal variability - is thus closely linked with the $F 2$ axis and that with its negative end since maximum activity in all seasons is achieved at SK2 (Fig. 2B). Of abiotic factors, those most firmly linked with the $\mathrm{F} 2$ axis are $\mathrm{v}, \mathrm{NO}_{3}{ }^{-}, \mathrm{NH}_{4}{ }^{+}$, and $\mathrm{P}_{t}$ with the negative end and $\mathrm{DO} \%$ with the positive end (Fig. 3). All of these parameters with statistical significance decrease $(\mathrm{DO} \%)$ or increase $\left(\mathrm{v}, \mathrm{NO}_{3}{ }^{-}, \mathrm{NH}_{4}{ }^{+}\right.$, and $\left.\mathrm{P}_{t}\right)$ at SK2 in relation to the control locality and (with the exceptions of
$\mathrm{NH}_{4}{ }^{+}$and $\mathrm{NO}_{3}{ }^{-}$) are characterized by statistically significant recovery downstream (Fig. 4B, G, I, K, M). This is also indicated by the existence of statistically significant correlation between GPx activity and v $(R=0.706, P=0.002), \mathrm{DO} \%$ $(R=-0.545, P=0.029), \mathrm{NH}_{4}{ }^{+}(R=0.501, P=0.048)$, and $\mathrm{NO}_{3}{ }^{-}(R=0.868, P<0.001$; Fig. 5A $)$.

\section{Discussion}

In view of the increase in the number of trout farms witnessed in recent years in Serbia, investigations are needed that through fast physiological responses of individuals will indicate the changes that will inevitably occur in the whole community of macroinvertebrates (Gremyatchikh et al., 2009). The enzymes SOD and GPx and tripeptide GSH in larvae of E. danica as a model organism represent reliable biomarkers in judging the early response of aquatic organisms to organic pollution, a circumstance that offers the opportunity to make an important contribution in the field of ecophysiology of aquatic organisms (Hook et al., 2014).

It is known that one of the main sources of pollution of streams on which trout farms are constructed is the discharge of effluents containing remains of fish feed and fecal matter from the fish farm (Kronvang et al., 1993; Iversen, 1995). These effluents affect chemical parameters of the recipient stream, leading to increase in the concentration of total phosphorus and nitrogen compounds and decrease of dissolved oxygen concentration (Foy and Rosell, 1991; Boaventura et al., 1997; Selong and Helfrich, 1998; Pulatsu et al., 2004; Bartoli et al., 2007; Živić et al., 2009a; Camargo et al., 2011; Silva et al., 2012). Such changes of chemical factors through increase/decrease of the mentioned parameters lead to worsening of water quality and cause (among other things) oxidative stress in aquatic organisms (Boaventura et al., 1997; Livingstone, 2001, 2003).

In this study, trout farm effluents induced statistically significant increase of $\mathrm{NO}_{3}{ }^{-}, \mathrm{NH}_{4}{ }^{+}$, and $\mathrm{P}_{t}$ and the decrease of DO and $\mathrm{DO} \%$ at SK2, a downstream locality closest to the trout farm. These changes could be directly explained by the arrival of unutilized fish feed and feces from the trout farm into the recipient and subsequent eutrophication (Boaventura et al., 1997; Briand et al., 2003). The most sensitive component of antioxidative defense of E. danica to these changes in water chemistry was GPx, whose activity reached maximum at SK2 in all seasons of investigation and showed statistically significant correlation with $\mathrm{NO}_{3}{ }^{-}, \mathrm{NH}_{4}{ }^{+}$, and DO\%. GPx is an enzyme that catalyzes reduction of $\mathrm{H}_{2} \mathrm{O}_{2}$ and lipid peroxides. Similar high sensitivity of GPx to trout farm pollution was observed in Gammarus dulensis in the Crnica River (Vranković et al., 2018). Additionally, study of Duman and Kar (2015) supports our results with the conclusion that GPx enzyme is the first-line antioxidant defense enzyme in Gammarus pulex. Significant seasonal variation in the activity of GPx was observed only at SK2 locality, with a large decrease in summer, followed by a gradual but incomplete recovery toward winter (Fig. 2B). Lowest activity of glutathione peroxidase during summer was also observed in molluscs of the species Tapes philippinarum and Mytilus galloprovincialis (Bocchetti et al., 2008). 

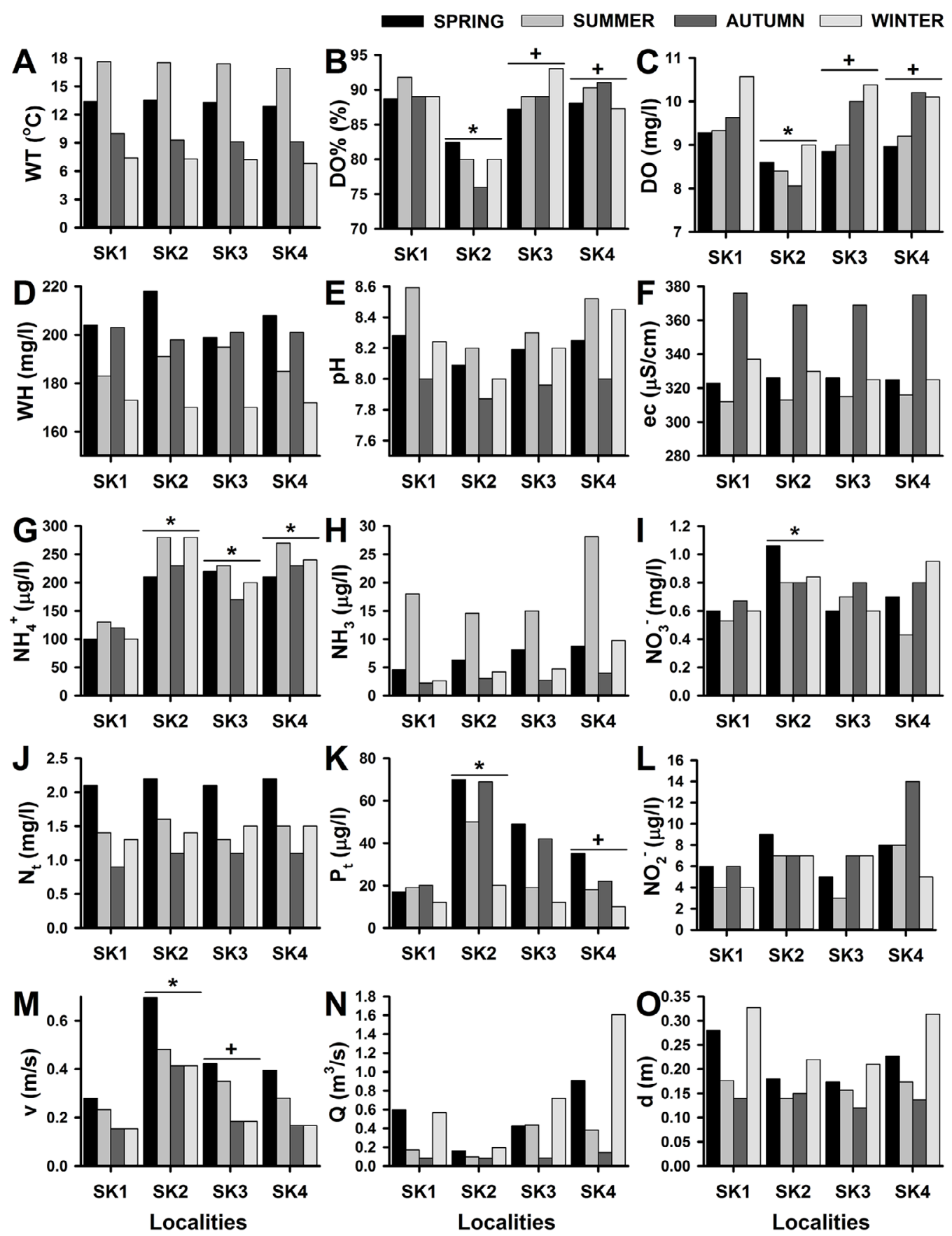

Fig. 4. Values of hydrological and chemical parameters of the water (see Materials and methods section for codes) at four sampling sites (SK1, SK2, SK3 and SK4) along the Skrapež River measured in spring (April) summer (July), autumn (October) and winter (January). Statistically significant difference $(P<0.05)$ of values of abiotic parameters at downstream localities compared to the values at the control locality (SK1) is marked with an asterisk $(*)$, and compared to the values at SK2 locality with a plus $(+)$.

Effects of trout farm on abiotic parameters in the recipient watercourse are clear but of mild intensity since values of affected environmental parameters $\left(\mathrm{NO}_{3}{ }^{-}, \mathrm{NH}_{4}{ }^{+}, \mathrm{P}_{t}\right.$, and DO) stayed well within the limits prescribed for salmonid waters $\left(\leq 0.2 \mathrm{mg} / \mathrm{L}\right.$ for $\mathrm{P}_{t}, \leq 1 \mathrm{mg} / \mathrm{L}$ for $\mathrm{NH}_{4}{ }^{+}$, and $\geq 7 \mathrm{mg} / \mathrm{L}$ at $100 \%$ saturation for DO, TEPCD, 2006 and $\leq 2 \mathrm{mg} \mathrm{NO}_{3}{ }^{-} \mathrm{N} / 1$ for $\mathrm{NO}_{3}{ }^{-}$; Camargo et al., 2005). The effect of the trout farm on DO at SK2 would be more severe if not for small water depth and high water velocity at that locality (Fig. 4M, O). Such a mild effect could be an explanation why activity of SOD stayed largely unaffected by the trout farm effects. This was not expected since SOD usually represents the first line of defense of an organism against reactive oxygen species and plays a key role in protecting the cell from oxidative damage. This enzyme transforms the highly reactive radical into a less reactive form of oxygen, hydrogen peroxide, and molecular oxygen (Alscher et al., 2002; Zelko et al., 2002; Bafana et al., 2011). Our investigation shows that activity of SOD characterized 

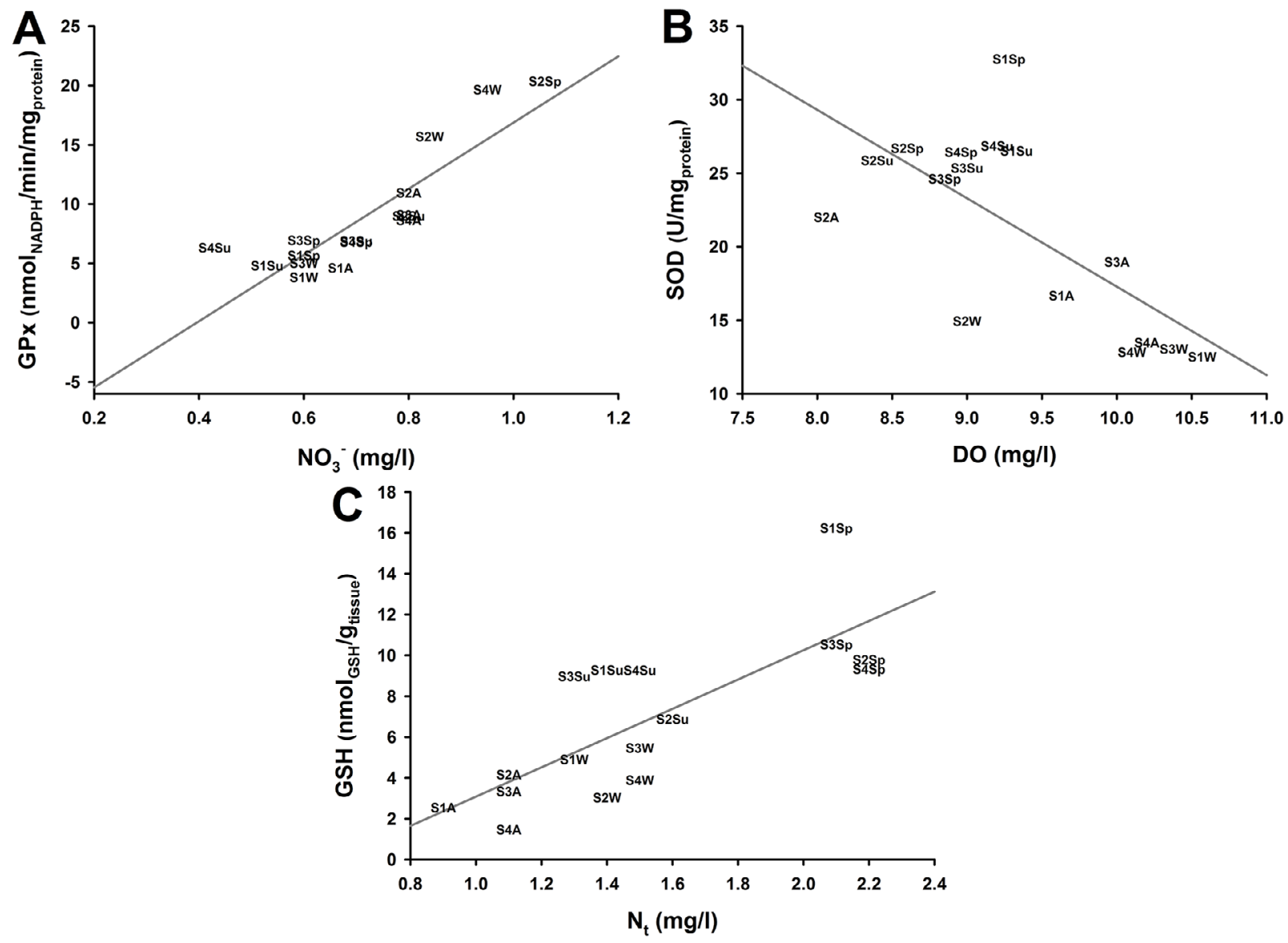

Fig. 5. Effects of environmental factors on antioxidant enzyme activities in E. danicae. (A) Effect of changes in $\mathrm{NO}_{3}{ }^{-}$during the investigation period on GPx activity at the investigated localities on the Skrapež River. The solid line represents the linear fit of the data $(R=0.868$, $P<0.001$ ). (B) Effect of changes in DO during the investigation period on SOD activity at the investigated localities on the Skrapež River. The solid line represents the linear fit of the data $(R=-0.678, P=0.004)$. (C) Effect of changes in $\mathrm{N}_{t}$ during the investigation period on SOD activity at the investigated localities on the Skrapež River. The solid line represents the linear fit of the data $(R=0.771, F=20.5, P<0.001)$.

statistically significant seasonal but not longitudinal changes, which are correlated with the changes in DO, $\mathrm{N}_{t}$, and WT. In regard to the control locality, a decrease of SOD activity occurs from spring to winter (Fig. 2A). In view of the fact that activity of SOD is in statistically significant correlation with temperature, increased activity of this enzyme in spring and summer in relation to autumn and winter can be explained as being a consequence of the increased temperature in these seasons (Fig. 4A). According to some authors, decrease in the activity of antioxidant enzymes during the winter season is a consequence of metabolic changes linked with the physiological status of animals (Viarengo et al., 1990; Regoli et al., 1998; Livingstone, 2001). In general, the total metabolism of an organism increases under conditions of high temperatures, and enzyme activity increases as a result. Buchner et al. (1996) showed that activity of SOD increases under conditions of moderate increase of temperature. Also, seasonally related variability of SOD was noticed in the mollusc Saccostrea cucullata by Niyogi et al. (2001), who recorded maximal activity in summer. Higher activity of SOD in summer than in winter was also recorded in the snail Nacella concinna (Abele et al., 1998). On the other hand, Doucet-Beaupré et al. (2010) showed that activity of the enzyme SOD in the molluscs
Pyganodon grandis and $P$. fragilis was independent of temperature.

Looking at the spring season, we see that activity of SOD is greater at the control locality (SK1) than at the locality immediately below the fish farm (SK2) (Fig. 2A). Similar results were obtained by Vranković et al. (2012), who measured the greatest SOD activity in specimens of Holandriana holandrii taken at the reference (control) locality, which had no noticeable sources of pollution. Such a response of SOD is a result of increased production of superoxide due to intensification of normal physiological processes (Vranković et al., 2012). Activity of SOD in our investigations is strongly influenced by changes in factors of the internal and external environment caused by the succession of seasons, since with respect to the amplitude of activity and concentration, and in regard to the pattern of their seasonal changes, the localities downstream from the fish farm's outlet are very similar to the control locality. An exception is autumn, when SOD activity attains a maximum at SK2 (Fig. 2A) just as in case of GPX. This is the consequence of minimal values of river flow in autumn $\left(0.10 \mathrm{~m}^{3} / \mathrm{s}\right.$; Fig. $\left.4 \mathrm{~N}\right)$, which due to maintenance of a constant throughput through the trout farm should increase trout farm's influence on the recipient stream enough to 
significantly affect SOD activity. Indeed, DO, which is strongly correlated with SOD activity, reached its lowest value $(8.06 \mathrm{mg} / \mathrm{L}$, Fig. $4 \mathrm{C})$ precisely in autumn at SK2 and could be the main reason of the change in longitudinal pattern of SOD activity. Mirčić et al. (2016) investigated the influence of a trout farm on longitudinal changes in SOD activity in the species Dinocras megacephala and showed its negative correlation with DO, just like in our study.

It is known that glutathione peroxidase for its activity makes use of cofactors, viz., low-molecular-weight thiols such as glutathione (GSH) (Birben et al., 2012). Meanwhile, glutathione - aside from being a cofactor - takes part in antioxidant defense by directly removing free radicals and hydroperoxide, makes possible the regeneration of nonenzymatic antioxidants to active forms, participates in repair of oxidative damage to DNA molecules, and prevents apoptosis caused by ROS (Kruidenier and Verspaget, 2002). The concentration of glutathione in our investigation is characterized by greater seasonal than longitudinal variability (Fig. 2C). Additionally, it is strongly correlated with SOD activity (Fig. 2D) since spring and summer concentrations at each locality are greater than autumn and winter ones, with maximal values in spring attained at the control locality and in autumn at SK2. Despotović et al. (2012) found that changes of glutathione content in the species Viviparus acerosus are under considerable seasonal influence, so that the concentration of GSH decreases significantly from July to September. The level of GSH in the digestive gland of Fulvia fragilis was significantly higher in summer than in winter (Mahmoud et al., 2010). In the contrast to SOD, summer and winter values of GSH are characterized by a statistically significant minimum at SK2 (Fig. 2C). Decrease in the concentration of GSH at SK2 can be attributed to increase in the activity of glutathione peroxidase, since it is known that enzymes that utilize GSH as a cofactor or cosubstrate (GPx) bring about depletion of GSH by transforming it into GSSG (Birben et al., 2012). In other studies also, it was found that a reduced concentration of GSH is in positive correlation with increase of GPx activity (Kruidenier and Verspaget, 2002; Despotović et al., 2012).

\section{Conclusions}

On the basis of the obtained results, it can be concluded that the trout farm at the Skrapež River had mild but clear influence on the water chemistry parameters in the receiving watercourse. At SK2, a downstream locality closest to the trout farm, changes in most strongly influenced parameters $\left(\mathrm{NO}_{3}{ }^{-}, \mathrm{NH}_{4}{ }^{+}\right.$, $\mathrm{P}_{t}$, DO, and DO\%) were statistically significant, but their almost complete recovery was noted further downstream. However, their values remained well within the limits prescribed for salmonid waters.

The most sensitive component of antioxidative defense of E. danica to these changes in water chemistry was GPx, whose activity reached maximum at SK2 in all seasons and showed statistically significant correlation with $\mathrm{NO}_{3}{ }^{-}, \mathrm{NH}_{4}{ }^{+}$, and DO\%. Thus, GPx represents the first line of antioxidant defense in E. danica in the conditions of stress induced by the trout farm effluents. Activity of SOD and GSH concentration were less sensitive to the trout farm stress and more strongly influenced by changes in factors of the internal and external environment caused by the succession of seasons. The environmental parameters most strongly influencing these biomarkers were WT, DO, and $\mathrm{N}_{t}$. The only exception was in autumn, when due to low river flow effect of the trot farm effluents was strong enough to alter SOD activity and GSH concentration.

Therefore, changes in GPx and to a lesser extent SOD and GSH in E. danica proved to be reliable and sensitive biochemical biomarkers of environmental stress caused by the trout farm effluents, making this species an excellent bioindicator of freshwater pollution.

Acknowledgements. This study was supported by the Serbian Ministry of Education, Science and Technological Development (project No. TR 31075).

\section{References}

Abele D, Burlando B, Viarengo A, Pörtner H. 1998. Exposure to elevated temperatures and hydrogen peroxide elicits oxidative stress and antioxidant response in the Antarctic intertidal limpet Nacella concinna. Comp Biochem Phys B 120: 425-435.

Alscher RG, Erturk N, Heath LS. 2002. Role of superoxide dismutases (SODs) in controlling oxidative stress in plants. $J$ Exp Bot 53: 1331-1341.

Bafana A, Dutt S, Kumar A, Kumar S, Ahuja PS. 2011. The basic and applied aspects of superoxide dismutase. J Mol Catal B 68: 129-138.

Barata C, Varo I, Navarro JC, Arun S, Porte C. 2005. Antioxidant enzyme activities and lipid peroxidation in the freshwater cladoceran Daphnia magna exposed to redox cycling compounds. Comp Biochem Physiol 140: 175-186.

Bartoli M, Nizzoli D, Longhi D, Laini A, Viaroli P. 2007. Impact of a trout farm on the water quality of an Apennine creek from daily budgets of nutrients. Chem Ecol 23: 1-11.

Bauernfeind E, Soldan, T. 2012. The Mayflies of Europe (Ephemeroptera). Denmark: Apollo Books, 778 p.

Bennett C. 2007. A seven year of the life cycle of the mayfly Ephemera danica. Freshw Biol 27: 3-14.

Berra E, Forcella M, Giacchini R, Marziali L, Rossaro B, Parenti P. 2004. Evaluation of enzyme biomarkers in freshwater invertebrates from Taro and Ticino river, Italy. Ann Limnol Int J Lim 40: 169-180.

Birben E, Sahiner UM, Sackesen C, Erzurum S, Kalayci O. 2012. Oxidative stress and antioxidant defence. World Allergy Organ J 5: 9-19.

Boaventura R, Pedro AM, Coimbra J, Lencastre E. 1997. Trout farm effluents: characterization and impact on the receiving streams. Environ Pollut 95: 379-387.

Bocchetti R, Virno Lamberti C, Pisanelli B, Razzetti EM, Maggi C, Catalano B, Sesta G, Martuccio G, Gabellini M, Regoli F. 2008. Seasonal variations of exposure biomarkers, oxidative stress responses and cell damage in the clams, Tapes philippinarum, and mussels, Mytilus galloprovincialis, from Adriatic Sea. Mar Environ Res 66: 24-26.

Bonada N, Prat N, Rash VH, Statzner B. 2006. Developments in aquatic insect biomonitoring: a commparative analysis of recent approaches. Annu Rev Entomol 51: 495-523.

Boyd CE. 2003. Guidelines for aquaculture effluent management at the farm-level. Aquaculture 226: 101-112.

Božanić M, Perić-Mataruga V, Todorović D, Živić M, Stojanović K, Radojević A, Živić I. 2017. Uticaj pastrmskog ribnjaka na antioksidativnu odbranu larvi Ephemera danica (Insecta: Ephemeroptera). 
XI Simpozijum entomologa Srbije 2017, sa međunarodnim učešćem, Goč, 17-21 Septembar, Zbornih plenarnih referata i rezimea, 87-88 (in Serbian).

Bradford MM. 1976. A rapid and sensitive method for the quantity of microgram quantities of protein utilizing the principle of protein dye binding. Anal Biochem 72: 248-254.

Briand J, Jacquet S, Bernard C, Humbert J. 2003. Health hazards for terrestrial vertebrates from toxic cyanobacteria in surface water ecosystems. Vet Res 34: 361-377.

Brittain JE, Sartori M. 2003. Ephemeroptera (mayflies). In: Resh VH, Cardé RT, eds. Encyclopedia of Insects. Amsterdam: Academic Press, pp. 373-380.

Buchner T, Abele-Oeschger D, Theede H. 1996. Aspects of antioxidant status in the polychaete Arenicola marina: tissue and subcellular distribution, and reaction to environmental hydrogen peroxide and elevated temperatures. Mar Ecol Prog Ser 143: $141-150$.

Buonocore G, Perrone S, Tataranno ML. 2010. Oxygen toxicity: chemistry and biology of reactive oxygen species. Semin Fetal Neonatal Med 15: 186-190.

Camargo JA, Alonso A, Salamanca A. 2005. Nitrate toxicity to aquatic animals: a review with new data for freshwater invertebrates. Chemosphere 58: 1255-1267.

Camargo JA, Gonzalo C, Alonso Á. 2011. Assessing trout farm pollution by biological metrics and indices based on aquatic macrophytes and benthic macroinvertebrates: a case study. Ecol Indic 11: 911-917.

Carter JL, Resh VH, Rosenberg DM, Reynoldson TB. 2006. Biomonitoring in North American rivers: a comparison of methods used for benthic macroinvertebrates in Canada and the United States. In: Ziglio G, Flaim G, Sillgardi M, eds. Biological Monitoring of Rivers. New York: John Wiley \& Sons Ltd., pp. 203 228.

Choi J, Roche H, Caquet T. 1999. Characterization of superoxide dismutase activity in Chironomus riparius $\mathrm{Mg}$. (Diptera, Chironomidae) larvae, a potential biomarker. Comp Biochem Physiol 124: 73-81.

Despotović SG, Perendija BR, Gavrić JP, Borković-Mitić SS, Paunović MM, Pavlović SZ, Saičić ZS. 2012. Seasonal changes in oxidative stress biomarkers of the snail Viviparus acerosus from the Velika Morava River, Serbia. Arch Biol Sci 64: 953-962.

Dolédec S, Chessel D. 1994. Co-inertia analysis: an alternative method for studying species-environment relationships. Freshw Biol 31: 277-294.

Doucet-Beaupré H, Dubé C, Breton S, Pörtner HO, Blier PU. 2010. Thermal sensitivity of metabolic enzymes in subarctic and temperate freshwater mussels (Bivalvia: Unionoida). $J$ Therm Biol 35: 11-20.

Duman F, Kar M. 2015. Evaluation of effects of exposure conditions on the biological responses of Gammarus pulex exposed to cadmium. Int $J$ Environ Sci Technol 12: 437-444.

Estevez E, Rodríguez-Castillo T, Álvarez-Cabria M, Penas FJ, González-Ferreras AM, Lezcano M, Barquín J. 2017. Analysis of structural and functional indicators for assessing the health state of mountain streams. Ecol Indic 72: 553-564.

Foy RH, Rosell R. 1991. Fractionation of phosphorus and nitrogen loadings from a Northern Ireland fish farm. Aquaculture 96: $31-42$.

Gavrilović Lj, Dukić D. 2002. Reke Srbije. Zavod za udžbenike i nastavna sredstva, Beograd, 218 p. (in Serbian).

Gremyatchikh V, Tomilina II, Grebenyuk LP. 2009. The effect of mercury chloride on morphofunctional parameters in Chironomus riparius Meigen (Diptera, Chironomidae) larvae. Inland Water Biol 1: 89-95.
Griffith OW. 1980. Determination of glutathione and glutathione disulfide using glutathione reductase and 2 vinyl pyridine. Anal Biochem 106: 207-212.

Halliwell B, Gutteridge JMC. 1999. Free radicals in biology and medicine. In: Halliwell B, Gutteridge JMC, eds. Free Radicals in Biology and Medicine, 3rd ed. Oxford: Oxford University Press, pp. 1-25.

Hook SE, Gallagher EP, Batley GE. 2014. The role of biomarkers in the assessment of aquatic ecosystem health. Integr Environ Assess Manag 10: 327-341.

Imanpour N, Sharifinia M, Makrani AB. 2013. Assessment of fish farm effluents on macroinvertebrates based on biological indices in Tajan River (north Iran). Caspian J Env Sci 11: 29-39.

Iversen TM. 1995. Fish farming in Denmark: environmental impact of regulative legislation. Water Sci Technol 31: 73-84.

Kronvang B, Ertebjerg G, Grant R, Kristensen P, Hovmand M, Kirkegard J. 1993. Nation wide monitoring of nutrients and their ecological effects: state of the Danish aquatic environmental. Ambio 22: 176-187.

Kruidenier L, Verspaget HW. 2002. Review article: oxidative stress as a pathogenic factor in inflammatory bowel disease - radicals or ridiculous. Aliment Pharmacol Ther 16: 1997-2015.

Lemaire P, Livingstone DR. 1993. Pro-oxidant/antioxidant processes and organic interactions in marine organisms, in particular the flounder Platichthys flesus and the mussel Mytilus edulis. Trends Comp Biochem Physiol 1: 1119-1147.

Livingstone DR. 2001. Contaminant-stimulated reactive oxygen species nproduction and oxidative damage in aquatic organisms. Mar Pollut Bull 42: 656-666.

Livingstone DR. 2003. Oxidative stress in aquatic organisms in relation to pollution and aquaculture. Rev Med Vet Toulouse 154: 427-430.

Loch DD, West JL, Perlmutter DG. 1996. The effect of trout farm effluent on the taxa richness of benthic macroinvertebrates. Aquaculture 147: 37-55.

Lock K, Goethals PLM. 2011. Distribution and ecology of the mayflies (Ephemeroptera) of Flanders (Belgium). Int J Limnol 47: $159-165$.

Lushchak VI. 2011. Environmentally induced oxidative stress in aquatic animals. Aquat Toxicol 101: 13-30.

Mahmoud N, Dellali M, El Bour M, Aissa P, Mahmoudi E. 2010. The use of Fulvia fragilis (Mollusca: Cardiidae) in the biomonitoring of Bizerta lagoon: a multimarkers approach. Ecol Indic 10: 696-702.

Marković Z, Poleksć V, Živić I, Stanković M, Ćuk D, Spasić M, Dulić Z, Rašković B, Ćirić M, Bošković D, Vukojević D. 2009. Stanje ribarstva u Srbiji. In: Conference Proceedings VII International Conference "Water \& Fish", Faculty of Agriculture, University of Belgrade - Serbia, May, 27-29, 2009, Belgrade, Serbia, pp. 30-39 (in Serbian).

Mirčić D, Stojanović K, Živić I, Todorović D, Stojanović D, Dolićanin Z, Perić-Mataruga V. 2016. The troutfarm effect on Dinocras megacephala (Plecoptera: Perlidae) larvae: antioxidative defense. Environ Toxicol Chem 35: 1775-1782.

Misra HP, Fridovich I. 1972. The role of superoxide anion in the antioxidation of epinephrine and a simple assay for superoxide dismutase. J Biol Chem 247: 3170-3175.

Namin JI, Sharifinia M, Makrani AB. 2013. Assessment of fish farm effluents on macroinvertebrates based on biological indices in Tajan River (north Iran). Can J Earth Sci 11: 29-39.

Newman CM. 1995. Quantitative Methods in Aquatic Ecotoxicology, Advances in Trace Substances Research. Boca Raton, FL: Lewis Publishers, $448 \mathrm{p}$. 
Nilsson AN. 1996. Aquatic Insects of North Europe: A Taxonomic Handbook. Volume 1: Ephemeroptera, Plecoptera, Heteroptera, Neuroptera, Megaloptera, Coleoptera, Trichoptera, Lepidoptera. Denmark: Apollo Books, 274 p.

Niyogi S, Biswas S, Sarker S, Datta AG. 2001. Antioxidant enzymes in brackish water oyster, Saccostrea cucullata as potential biomarkers of polyaromatic hydrocarbon pollution in Hooghly Estuary (India): seasonality and its consequences. Sci Total Environ 281: 237-246.

Pulatsu S, Rad F, Köksal G, Aydın F, Benli AK, Topçu A. 2004. The impact of rainbow trout farm effluents on water quality of Karasu stream, Turkey. Turk J Fish Aquat Sci 4: 9-15.

Radojević A, Mirčić D, Živić M, Perić-Mataruga V, Todorović D, Božanić M, Živić I. 2017. Antioksidativni status larvi Ecdyonurus venosus (Ephemeroptera: Heptagenidae): Uticaj pastrmskih ribnjaka. XI Simpozijum entomologa Srbije 2017, sa međunarodnim učešćem, Goč, 17-21 Septembar, Zbornih plenarnih referata i rezimea, pp. 88-89 (in Serbian).

Regoli F, Hummel H, Amirad-Triquet C, Larroux C, Sukhotin, A. 1998. Trace metals and variations of antioxidant enzymes in Arctic bivalve populations. Arch Environ Contam Toxicol 35: 594-601.

Selong JH, Helfrich LA. 1998. Impacts of trout culture effluent on water quality and biotic communities in Virginia headwater streams. Prog Fish Cult 60: 247-262.

Silva C, Mattioli M, Fabbri E, Yáñez E, Delvalls TA, Martín-Díaz ML. 2012. Benthic community structure and biomarker responses of the clam Scrobicularia plana in a shallow tidal creek affected by fish farm effluents (Rio San Pedro, SW Spain). Environ Int 47: 86-98.

Soofiani NM, Hatami R, Hemami MR, Ebrahimi E. 2012. Effects of trout farm effluent on water quality and the macrobenthic invertebrate community of the Zayandeh-Roud River, Iran. N Am J Aquac 74: 132-141.

SRPS ISO/IEC 17025:2006. ISO/IEC 17025:2005. Available at http://www.sepa.gov.rs

Tamura M, Oschino N, Chance B. 1982. Some characteristics of hydrogen and alkyl-hydroperoxides metaboliying systems in cardiac tissue. J Biochem 92: 1019-1031.

Tello A, Corner RA, Telfer TC. 2010. How do land-based salmonid farms affect stream ecology? Environ Pollut 158: 1147-1158.

TEPCD 2006. The European Parliament and the Council Directive 2006/44/EC of 6 September 2006, on the quality of fresh waters needing protection or improvement in order to support fish life. Official Journal of the European Union, L 264/20. http://data. europa.eu/eli/dir/2006/44/oj
Thioulouse J, Chessel D, Dolédec S, Olivier JM. 1997. ADE-4: a multivariate analysis and graphical display software. Stat Comput 7: $75-83$.

Valavanidis A, Vlahogianni T, Dassenakis M, Scoullos M. 2006. Molecular biomarkers of oxidative stress in aquatic organisms in relation to toxic environmental pollutants. Ecotoxicol Environ Saf 64: $178-189$.

Viarengo A, Canesi L, Pertica M, Poli, G, Moore MN, Orunesu M. 1990. Heavy metal effects on lipid peroxidation in the tissues of Mytilus galloprovincialis. Comp Biochem Physiol C 97: 37-42.

Vranković J. 2016. Age-related changes in antioxidant and glutathione S- transferase enzyme activities in the Asian clam. Biochemistry 81: 339-349.

Vranković J, Slavić M. 2015. Biomarker responses in Corbicula fluminea to the presence of dioxin-like polychlorinated biphenyls and seasonal changes. Ecol Ind 48: 99-106.

Vranković J, Labus-Blagojević S, Csanyi B, Makovinska J, Cvetković O, Gačić Z, Blagojević D, Paunović M. 2012. Antioxidant enzymes and GST activity in natural populations of Holandriana holandrii from the Bosna River. Turk J Biol 36: 477-485.

Vranković J, Živić M, Radojević A, Perić-Mataruga V, Todorović D, Marković Z, Živić I. 2018. Evaluation of oxidative stress biomarkers in the freshwater gammarid Gammarus dulensis exposed to trout farm outputs. Ecotoxicol Environ Saf 163: 84-95.

Weston DP, Phillips MJ, Kelly LA. 1996. Environmental impacts of salmonid culture. Dev Aquac Fish Sci 29: 919-967.

Winkelmann C, Koop JHE. 2007. The management of metabolic energy storage during the life cycle of mayflies: a comparative Weld investigation of the collector-gatherer Ephemera danica and the scraper Rhithrogena semicolorata. J Comp Physiol B 177: 119-128.

Woynarovich A, Hoitsy G, Moth-Poulsen T. 2011. Small-scale rainbow trout farming. $F A O, 81 \mathrm{p}$.

Zelko IN, Mariani TJ, Folz RJ. 2002. Superoxide dismutase multigene family: a comparison of the CuZn-SOD (SOD1), Mn-SOD (SOD2), and EC-SOD (SOD3) gene structures, evolution, and expression. Free Rad Biol Med 33: 337-349.

Živić I, Marković Z, Filipović-Rojka Z, Živić M. 2009a. Influence of a trout farm on water quality and macrozoobenthos communities of the receiving stream (Trešnjica River, Serbia). Int Rev Hydrobiol 94: 673-687.

Živić I, Marković Z, Živić M. 2009b. Influence of a trout farm on macrozoobenthos communities of the Trešnjica River, Serbia. Arch Biol Sci 61: 483-492.

Cite this article as: Božanić MLJ, Todorović DD, Živić MŽ., Perić-Mataruga VD, Marković ZZ, Živić IM. 2018. Influence of a trout farm on antioxidant defense in larvae of Ephemera danica (Insecta: Ephemeroptera). Knowl. Manag. Aquat. Ecosyst., 419, 47. 